\title{
COVID-19 and Kidney Transplantation
}

\author{
Maurizio Salvadori ${ }^{1, *}$ and Aris Tsalouchos ${ }^{2}$ (D) \\ 1 Department of Renal Transplantation, Careggi University Hospital, viale Pieraccini 18, 50139 Florence, Italy \\ 2 Division of Nephrology, Santa Maria Annunziata Hospital, 50139 Florence, Italy; \\ aris.tsalouchos@uslcentro.toscana.it \\ * Correspondence: maurizio.salvadori1@gmail.com; Tel.: +39-055-597151
}

check for

updates

Citation: Salvadori, M.; Tsalouchos, A. COVID-19 and Kidney

Transplantation. Transplantology 2021,

2, 288-290. https://doi.org/

$10.3390 /$ transplantology2030027

Received: 9 July 2021

Accepted: 22 July 2021

Published: 26 July 2021

Publisher's Note: MDPI stays neutral with regard to jurisdictional claims in published maps and institutional affiliations.
The morbidity and mortality from COVID-19 are particularly high among patients with underlying health disease conditions and chronic disease, among which are kidney transplant recipients (KTRs). Several points merit to be discussed in order to better understanding the main topics concerning SARS-CoV-2 infection in KTRs.

First SARS-CoV-2 epidemiology in KTRs should be examined.

\section{SARS-CoV-2 Epidemiology in KTRs}

Two studies from the Columbia University and from Italy suggest that the incidence of COVID-19 in transplant patients is similar to that of patients on dialysis [1,2]. The characteristics of affected patients with more severe disease were older age and they had underlying comorbidities such as hypertension and diabetes mellitus.

Second, the best method to perform a diagnosis of SARS-CoV-2 infection should be established.

\section{Diagnosis}

Reverse transcription polymerase chain reaction (RT-PCR) assay of upper respiratory tract secretions is the current diagnostic test of choice, even if false positives and false negatives may occur [3].

\section{Manifestations and Clinical Outcomes}

As happens in the general population, KTRs with COVID-19 may have different clinical manifestations ranging from mild infection to multiple organ failure and death [4] It does appear that the incidence of severe complications may be more frequent in KTRs than in the general population [5].

\section{Renal Involvement}

Limited literature data from KTRs suggest it to be similar to that of general population with a high degree of acute kidney injury (AKI) and proteinuria. Additionally, it is not clear whether AKI is to be ascribed to hemodynamic changes or to a direct infection from SARS-CoV-2. An interesting report describes endothelialitis in the transplanted kidney [6].

\section{Outcomes}

The mortality ranges from $16 \%$ to $30 \%$ [7]. A similar incidence is reported by several registries.

\section{Management}

\section{Antiviral measures}

Remdesivir is investigated, but still now the access to the drug is limited and there is a lack of safety data [8]. Other antiviral medications such as Lopinavir and Ritonavir have a strong interaction with CNI metabolism.

Tocilizumab, an IL-6 antagonist is being used in patients with CRS [9]. The recent published data of the study RECOVERY [10] highlight its relevance. 


\section{Immunosuppression Management}

Patients with COVID-19 benefit from reduction of their target CNI through level and from a reduction of antimetabolites [11]. Those with moderate/severe disease may benefit of a further reduction in CNI trough level and of complete avoidance of antimetabolites.

Steroids should remain unchanged in patients with mild/moderate disease, while patients with critical disease should benefit of intravenous methylprednisolone.

\section{Other Drugs}

Studies on animals have suggested that ACE inhibitors and angiotensin-receptor blockers may upregulate ACE2 expression, increasing the target molecules for SARS-CoV-2. Recent data document the benefit of RAAS blockade [12]

Thrombofilia is associated with COVID-19 and several studies have documented the presence of macrothrombi and microthrombi. Prophylactic anticoagulation is recommended [13].

Several ongoing trials document the efficacy of complement inhibitors [14]. Indeed, the activation of complement component C3 exacerbates disease in SARS-CoV-2 infection.

\section{Vaccines}

Vaccination is recommended principally in the pre-transplant period. Additionally, in patients already transplanted, vaccination is recommended even if the immune response may be attenuated because of the immunosuppression.

Author Contributions: M.S. and A.T. conceptualized the study; M.S. and A.T. wrote and edited the manuscript. All authors have read and agreed to the published version of the manuscript.

Funding: This research received no external funding.

Institutional Review Board Statement: Not applicable.

Informed Consent Statement: Not applicable.

Conflicts of Interest: The authors declare no conflict of interest.

\section{References}

1. Alberici, F.; Delbarba, E.; Manenti, C.; Econimo, L.; Valerio, F.; Pola, A.; Maffei, C.; Possenti, S.; Lucca, B.; Cortinovis, R.; et al. A report from the Brescia Renal COVID Task Force on the clinical characteristics and short-term outcome of hemodialysis patients with SARS-CoV-2 infection. Kidney Int. 2020, 98, 20-26. [CrossRef] [PubMed]

2. Columbia University Kidney Transplant Program. Early Description of Coronavirus 2019 Disease in Kidney Transplant Recipients in New York. J. Am. Soc. Nephrol. 2020, 31, 1150-1156. [CrossRef] [PubMed]

3. West, C.P.; Montori, V.M.; Sampathkumar, P. COVID-19 Testing: The Threat of False-Negative Results. Mayo Clin. Proc. 2020, 95, 1127-1129. [CrossRef] [PubMed]

4. Banerjee, D.; Popoola, J.; Shah, S.; Ster, I.C.; Quan, V.; Phanish, M. COVID-19 infection in kidney transplant recipients. Kidney Int. 2020, 97, 1076-1082. [CrossRef] [PubMed]

5. Akalin, E.; Azzi, Y.; Bartash, R.; Seethamraju, H.; Parides, M.; Hemmige, V.; Ross, M.; Forest, S.; Goldstein, Y.D.; Ajaimy, M.; et al. Covid-19 and Kidney Transplantation. N. Engl. J. Med. 2020, 382, 2475-2477. [CrossRef] [PubMed]

6. Varga, Z.; Flammer, A.J.; Steiger, P.; Haberecker, M.; Andermatt, R.; Zinkernagel, A.S.; Mehra, M.R.; Schuepbach, R.A.; Ruschitzka, F.; Moch, H. Endothelial cell infection and endotheliitis in COVID-19. Lancet 2020, 395, 1417-1418. [CrossRef]

7. Nair, V.; Jandovitz, N.; Hirsch, J.S.; Nair, G.; Abate, M.; Bhaskaran, M.; Grodstein, E.; Berlinrut, I.; Hirschwerk, D.; Cohen, S.L.; et al. COVID-19 in kidney transplant recipients. Am. J. Transplant. 2020, 20, 1819-1825. [CrossRef] [PubMed]

8. Wang, Y.; Zhang, D.; Du, G.; Du, R.; Zhao, J.; Jin, Y.; Fu, S.; Gao, L.; Cheng, Z.; Lu, Q.; et al. Remdesivir in adults with severe COVID-19: A randomised, double-blind, placebo-controlled, multicentre trial. Lancet 2020, 395, 1569-1578. [CrossRef]

9. Zhang, S.; Li, L.; Shen, A.; Chen, Y.; Qi, Z. Rational Use of Tocilizumab in the Treatment of Novel Coronavirus Pneumonia. Clin. Drug Investig. 2020, 40, 511-518. [CrossRef] [PubMed]

10. The REMAP-CUP Investigators. Interleukin-6 Receptor Antagonists in Critically Ill Patients with COVID-19. N. Engl. J. Med. 2021, 384, 1491-1502. [CrossRef] [PubMed]

11. Zhong, Z.; Zhang, Q.; Xia, H.; Wang, A.; Liang, W.; Zhou, W.; Zhou, L.; Liu, X.; Rao, L.; Li, Z.; et al. Clinical characteristics and immunosuppressant management of coronavirus disease 2019 in solid organ transplant recipients. Am. J. Transplant. 2020, 20, 1916-1921. [CrossRef] [PubMed] 
12. Vaduganathan, M.; Vardeny, O.; Michel, T.; McMurray, J.J.; Pfeffer, M.A.; Solomon, S.D. Renin-Angiotensin-Aldosterone System Inhibitors in Patients with Covid-19. N. Engl. J. Med. 2020, 382, 1653-1659. [CrossRef] [PubMed]

13. Klok, F.A.; Kruip, M.J.H.A.; Van der Meer, N.J.M.; Arbous, M.S.; Gommers, D.A.M.P.J.; Kant, K.M.; Kaptein, F.H.J.; van Paassen, J.; Stals, M.A.M.; Huisman, M.V.; et al. Incidence of thrombotic complications in critically ill ICU patients with COVID-19. Thromb. Res. 2020, 191, 145-147. [CrossRef] [PubMed]

14. Risitano, A.M.; Mastellos, D.C.; Huber-Lang, M.; Yancopoulou, D.; Garlanda, C.; Ciceri, F.; Lambris, J.D. Complement as a target in COVID-19? Nat. Rev. Immunol. 2020, 20, 343-344. [CrossRef] [PubMed] 